\title{
Analisis Kualitas Data Magnetotelurik Berdasarkan Parameter Koherensi Studi Kasus: Data Magnetotelurik Di Daerah Bandung, Jawa Barat
}

\author{
G.M. Lucki Junursyah ${ }^{1)}$, Agus Prabowo ${ }^{2, a)}$ dan, Wahyu Hidayat ${ }^{\text {3) }}$ \\ 1) Pusat Survei Geologi, Jl. Diponegoro No. 57 Bandung Jawa Barat \\ ${ }^{2)}$ Teknik Geofisika, Fakultas Teknologi Mineral, Universitas Pembangunan Nasional "Veteran" Yogyakarta, \\ Jl. Pajajaran Condongcatur Depok Sleman DI Yogyakarta 55285 \\ ${ }^{3)}$ Teknik Geofisika, Institut Teknologi Bandung, FTTM, Jl. Ganesha No. 10 Bandung Jawa Barat \\ a) Email korespondensi: agsprbowo74@gmail.com
}

\begin{abstract}
ABSTRAK
Magnetotelurik atau dikenal dengan MT merupakan metode geofisika pasif yang mengukur variasi medan elektromagnetik alami bumi untuk menyelediki struktur bawah permukaan bumi pada kedalaman 10 meter sampai 10 kilometer berdasarkan sifat resistivitas bawah permukaan. Kualitas data merupakan suatu kunci untuk mendapatkan hasil interpretasi yang baik. Permasalahan utama dari data magnetotelurik adalah pengaruh noise reguler yang dapat mempengaruhi signal to noise ratio. Noise koheren umumnya dijumpai di daerah pengukuran yang dekat dengan sumber noise seperti instalasi listrik rumah tangga atau Saluran Udara Tegangan Ekstra Tinggi (SUTET). Untuk mengatasinya perlu dilakukan kajian analisis data berdasarkan parameter koherensi. Penelitian ini bertujuan untuk melakukan reduksi noise menggunakan teknik akuisisi dan pengolahan data. Penelitian ini memanfaatkan data pengukuran di daerah padat penduduk di Kota Bandung Jawa Barat dengan jumlah 25 titik pengukuran. Untuk meningkatkan S/N ratio (Signal to Noise ratio) dilakukan beberapa treatment data yaitu dengan menggunakan robust, time series, dan edit XPR. Hasil dari pengolahan tersebut terbukti dapat menaikan nilai koherensi pada setiap titik pengukuran dengan rata-rata nilai koherensi dari $65.32 \%$ menjadi rata-rata nilai $83.85 \%$ atau mengalami kenaikan sebesar $18.54 \%$. Penelitian ini membuktikan bahwa metode MT dapat dilakukan pada daerah perkotaan yang biasanya mempunyai banyak noise dengan meningkatkan kualitas data MT, dengan cara mereduksi noise yang terekam pada pengukuran untuk menigkatkan kulaitas data MT. Kualitas data MT yang baik mampu merepresentasikan keadaan bawah permukaan yang hampir mirip dengan sebenarnya.
\end{abstract}

Kata Kunci: Koherensi; magnetotelurik; noise; perkotaan; signal

\section{ABSTRACT}

Magnetotellurics, also known as MT, is a passive geophysical method that measures variations in the Earth's natural electromagnetic field to investigate subsurface structures in the depth of 10 meters to 10 kilometers based on resistivity value. Good data quality is a key in rsulting good interpretation. The main problem with magnetotellurics data is the influence of coherent noise which can affect the signal ratio. Reguler noise is generally found in the measurement area close to noise sources such as household electrical installations or Extra High Voltage Air Ducts (SUTET). To overcome this, it is necessary to analysis the data based on coherence parameters. This study aimed to conduct noise reduction using techniques of data acquisition and data processing. This study utilizes measurement data in densely populated areas in Bandung City, West Java with a total of 25 measurement points. To increase the $S$ / $N$ ratio, several data treatments were carried out by using robust, time series, and edit XPR. The results of this processing are proven to increase the coherence value at each measurement point with an average coherence value of $65.32 \%$ to an average value of $83.85 \%$ or an increase of $18.54 \%$. This study proves that the MT method can be carried out in urban areas that usually have a lot of noise by increasing the quality of MT data, by reducing the noise recorded in measurements to increase the quality of MT data. MT good quality data that is able to represent to subsurface that is almost similar to the real.

Keywords: Coherence; magnetotelluric; noise; signal; urban

\section{PENDAHULUAN}

Metode Magnetotelurik (MT) merupakan metode geofisika pasif yang mengukur variasi medan elektromagnetik alami bumi untuk menyelediki struktur bawah permukaan bumi pada kedalaman 10 meter sampai 10 kilometer berdasarkan sifat resistivitas elektrik bawah permukaan (Vozoff, 1990). Metode MT adalah teknik elektromagnetik pasif yang melibatkan pengukuran fluktuasi medan listrik (E) dan medan magnet (B). Terdapat dua jenis sumber pada metode ini, yaitu petir sebagai sumber frekuensi tinggi lebih dari $1 \mathrm{~Hz}$ dan badai matahari (aktivitas matahari yang menyebabkan adanya gelombang elektromagnetik) sebagai sumber dengan frekuensi rendah kurang dari $1 \mathrm{~Hz}$, metode MT menghasilkan frekuensi $10^{4}$ hingga $10^{-4} \mathrm{~Hz}$ (Unsworth, 2016). Rentang frekuensi yang begitu panjang, pengukuran MT seringkali terdapat gangguan sinyal data (noise) pada frekuensi tertentu (Vozoff, 1990). Noise yang muncul pada data 
MT dapat dikategorikan berdasarkan pengaruhnya dalam waktu tertentu yaitu regular noise dan irregular noise (Unsworth, 2016). Regular noise merupakan noise yang muncul pada rentang frekuensi tertentu seperti power line noise. Powerline noise timbul akibat sistem transmisi dan distribusi arus listrik rumah tangga dari PLN memiliki frekuensi 50 Hz. Irregular noise adalah noise yang tidak mengikuti trend data pada domain waktu seperti spike noise. Irregular noise dapat muncul dari pergerakan kendaraan yang menghasilkan noise medan magnet akibat vibrasi yang dirambatkan melalui tanah (Vozoff, 1990). Vibrasi ini dapat menggetarkan koil sensor magnetik yang dapat berpotensi merubah flux magnetik yang melewati koil. Gangguan semacam ini juga dapat terjadi akibat adanya aktivitas alam angin dan badai yang menggerakan batang pohon yang kemudian menimbulkan efek vibrasi.

Daerah Bandung merupakan daerah daerah perkotaan yang banyak mengandung noise jika dilakukan pengukuran menggunakan metode MT. Survei metode MT pada daerah perkotaan akan mengalami kesulitan dalam proses pengambilan data karena terpanguruh oleh noise regular dan ireguler. Penelitian ini bertujuan untuk melakukan reduksi noise menggunakan teknik akuisisi dan pengolahan data. Pada penelitian ini noise yang akan di reduksi adalah noise regular, reduksi noise dilakukan untuk meningkatkan kualitas data MT. Kualitas data MT yang baik dengan parameter koherensi akan lebih merepresentasikan keadaan bawah permukaan yang sebenarnya. Penelitian ini menggunakan acuan yaitu parameter koherensi, dimana memiliki rentang nilai 0 sampai 1 , angka 1 menunjukkan kualitas data yang sangat baik (Mwakirani, 2012). Untuk melihat data yang baik secara kuantitatif digunakan nilai acuan minimal koherensi 0.75 (Junursyah, 2016).

\section{METODE}

Penelitian menggunakan data pengukuran 25 titik di Kota Bandung, Jawa Barat. Sebaran titik - titik pengukuran dapat dilihat pada Gambar 1. Pengukuran dilakukan oleh Tim Survei MT Pusat Survei Geologi, Bandung dengan rentang waktu pengukuran dari tahun 2013 sampai 2016.

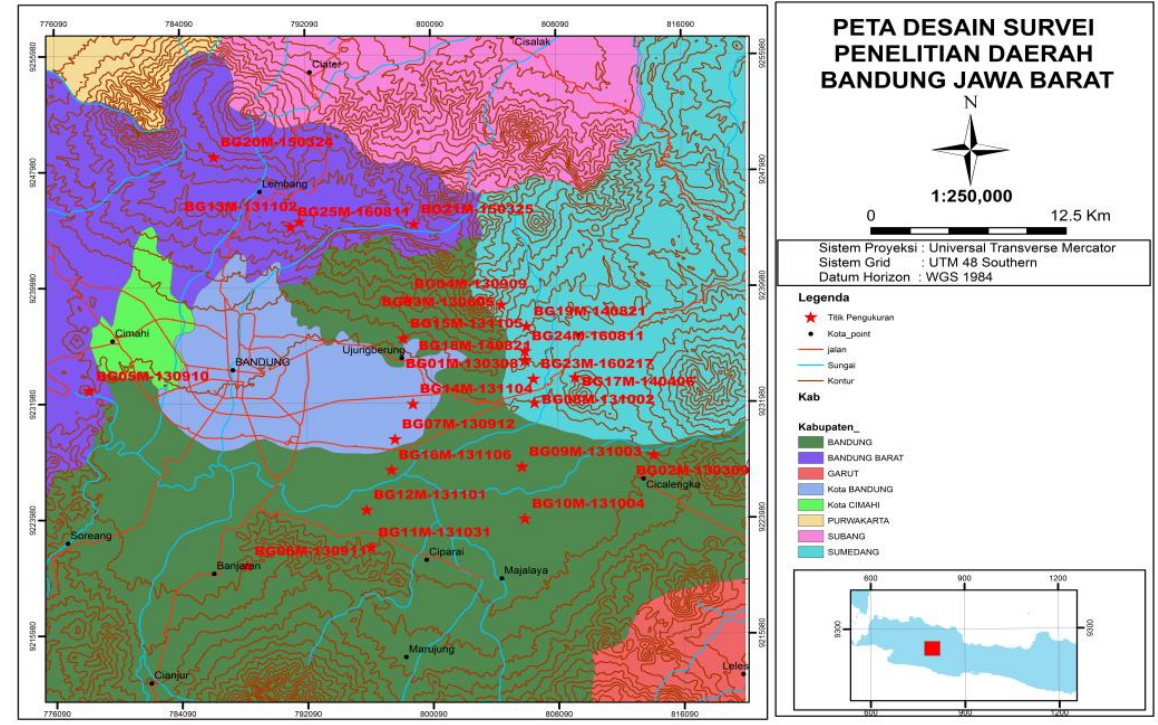

Gambar 1. Desain Survei Pengukuran MT (DEMNAS, 2019)

Data yang digunakan adalah data dari hasil pengukuran menggunakan alat MTU-5A (Phoenix Geophysics) dengan file ekstensi berupa : AMT*.TBL,AMT*.TS2,AMT*.TS3, AMT*.TS4, MT*.TBL, MT*TS3, MT*.TS4, MT*.TS5. Tahapan Proses penelitian dapat dilihat pada Gambar 2. 


\section{0}

JMEL, Volume 4 Nomor 2, 2020

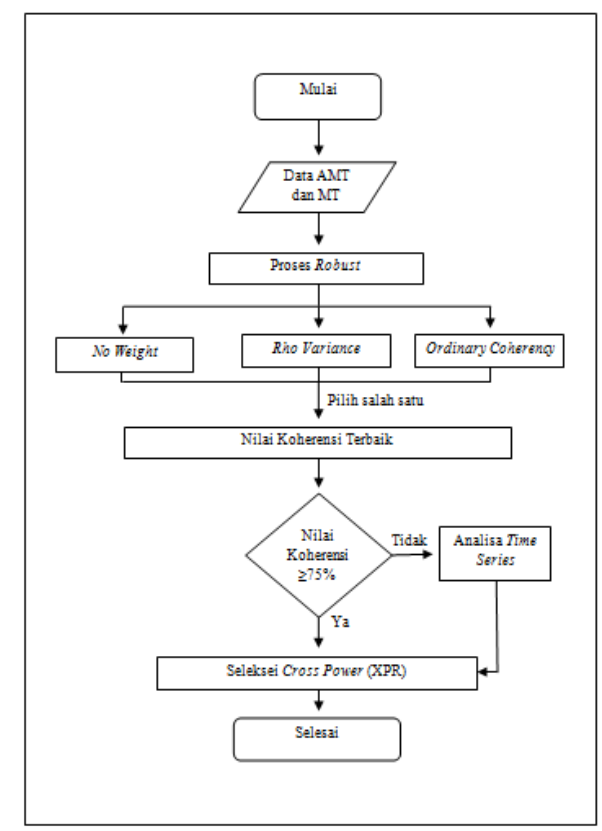

Gambar 2. Diagram alir Pengolahan

Distorsi sinyal atau gangguan akibat benda benda sekitar mengakibatkan noise. Untuk menghasilkan data yang baik diperlukan pengolahan dan analisis data yang mumpuni, Terdapat beberapa cara untuk meningkatkan kualitas data MT yaitu dengan robust, analisis time series, dan seleksi cross power (XPR). Koherensi sinyal merupakan bilangan nyata berdimensi dengan nilai $0 \leq \psi \leq 1$. Koherensi sinyal dinyatakan sebagai rasio spektral yang terdiri dari kolerasi spektrum medan listrik dan medan magnet $\left\langle\mathrm{E}^{*} \mathrm{H}\right\rangle$ (dengan * merupakan konjungasi kompleks) yang digunakan untuk menghitung fungsi transfer, dibagi dua auto power spectrum yang dapat dilihat pada Persamaan 1.

$$
\psi=\frac{(E * H)}{((E * E)(H * H))^{1 / 2}}
$$

Robust processing adalah teknik pemrosesan statistik yang menggunakan bobot iterative dari residual untuk mengidentifikasi dan menghapus data yang menyimpang oleh noise non-Gaussian. Robust processing menggunakan beberapa pengukuran dari departure suatu kontribusi individual dari rata-rata unuk merendahkan bobot outliers pada iterasi selanjutnya (Simpson \& Bahr, 2005). Proses ini berguna untuk mendeteksi outliers. Outliers adalah data yang memiliki nilai yang jauh dari nilai keseluruhan sehingga data tersebut diberikan pembobotan yang lebih kecil secara iteratif. Fungsi yang digunakan dalam proses pembobotan yaitu fungsi pembobot bisquare. Bentuk dari fungsi pembobot bisquare dapat dilihat pada Persamaan 2 (Muddasir. dkk, 2016).

$$
W_{i}=\left\{\begin{array}{r}
\left(1-\left(\frac{r_{i}}{\sigma M A D}\right)^{2}\right)^{2}, j i k a\left|r_{i}\right|<\sigma M A D \\
0, j i k a\left|r_{i}\right| \geq \sigma M A D
\end{array}\right.
$$

Dalam proses robust terdapat 3 macam parameter cross power yang digunakan diantaranya :

1. No Weight (NW), yang memberikan pembobotan yang sama pada setiap frekuensi, bisa disebut RAW data (data lapangan).

2. Rho Variance (RV) memberikan pembobotan yang besar pada data tahanan jenis pada data MT yang memiliki cuplikan sebanyak nilai cross power yang diinginkan.

3. Ordinary Coherence (OC), pembobotan besar akan diberikan pada frekuensi yang memilik koherensi yang baik diantara komponen $\mathrm{H}$ dan $\mathrm{E}$.

Analisis time series adalah proses untuk mereduksi noise dengan menganalisis sinyal koheren terhadap waktu dan juga memotong waktu yang terpengaruh noise tersebut. Data MT terdiri dari 3 rentang frekuensi yaitu TS3 (40-320 Hz), TS4 
(5.6-33 Hz) dan TS5 (0.00034-4.7 Hz). Pada TS3 dan TS4 memilik frekuensi yang tinggi (dekat permukaan) sehingga berisi data/sinyal yang diinginkan sedangkan TS5 berisi noise dengan sumber yang kuat (Gambar 3).

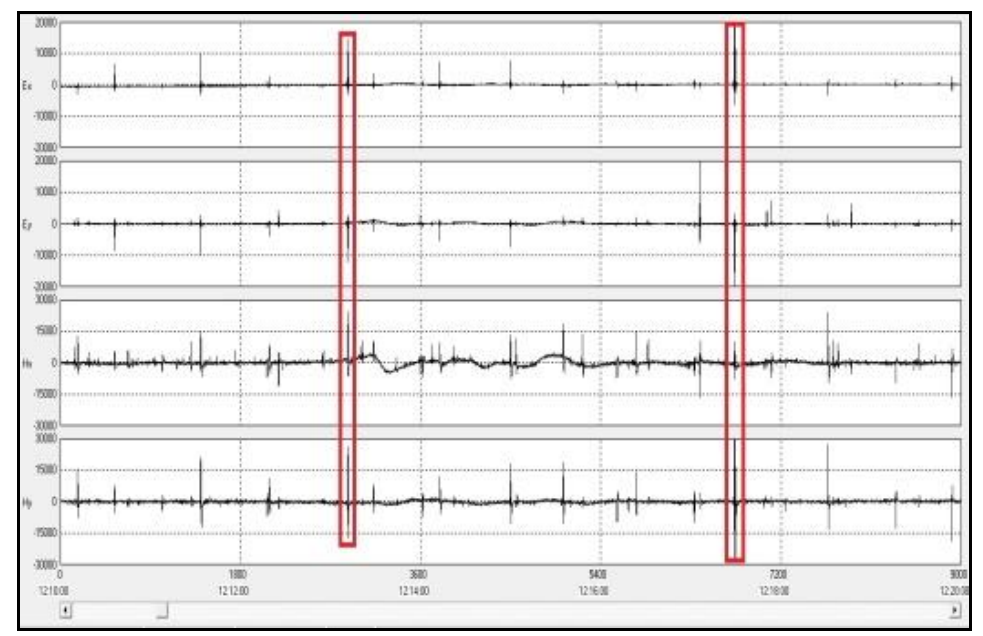

Gambar 3. Analisis Sinyal pada TS5 Stasiun BG 03 (TS Viewer)

Seleksi Crosspower (XPR) bertujuan untuk nilai koherensi memilih titik bobot pada setiap frekuensi dengan memperhatikan perubahan kurva dan nilai pembobotan pada grafik tahanan jenis semu dan fasa.

\section{HASIL DAN PEMBAHASAN}

Proses pengolahan robust merupakan tahapan awal dalam pengolahan data MT. Gambar 4 menunjukkan proses pengolahan robust dengan rho variance.

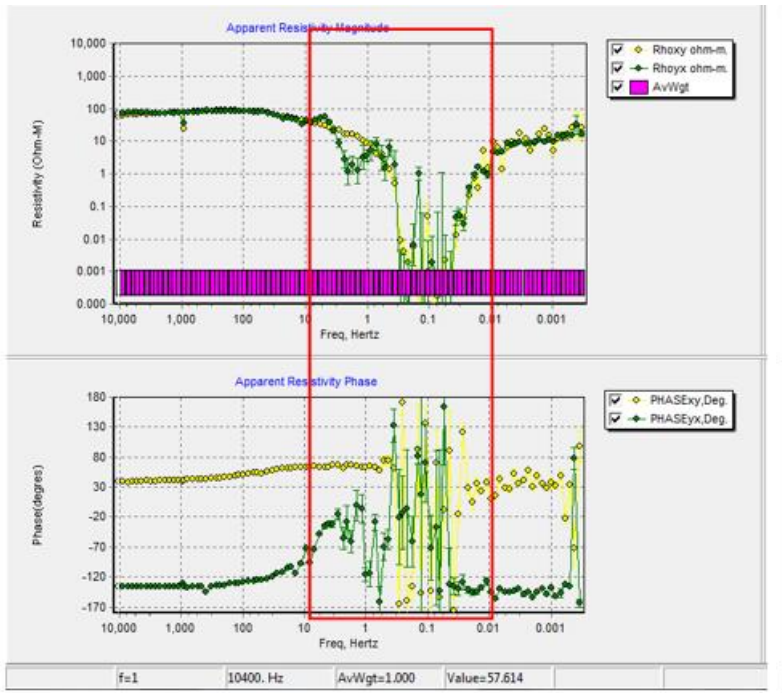

(a)

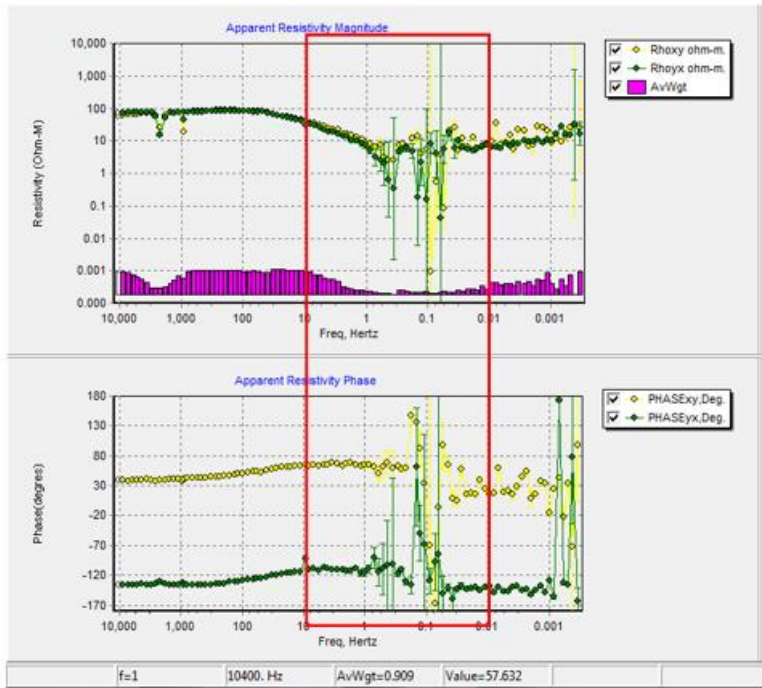

(b)

Gambar 4. a.) Grafik apparentresistivity magnitude dan phase yang merupakan $R A W$ data (NW) ; b) Grafik apparentresistivity magnitude dan phase yang Sudah dilakukan pengolahan robust (RV)

Dalam analisis secara kualitatif dapat dilihat dengan perubahan dari grafik yang setelah dilakukan pengolahan menjadi lebih smooth dibandingkan dengan data awalnya (NW). Dilihat dari kotak yang ditandai dengan garis merah yang merupakan terjadinya perubahan yang signifikan, jika dilihat dari grafik mendapatkan kenaikan yang lebih smooth. Jika dilihat dari analisis kuantitatif yang ditunjukkan dengan tabel 1 (Lampiran), dapat dilihat kenaikan nilai koherensi dari $R A W$ data $(\mathrm{NW})$ ke $R V .67 .66 \%$ merupakan data awal $(\mathrm{NW})$ pada stasiun ini yang kemudian dilakukan pengolahan robust dengan parameter RV menjadi $74.15 \%$. Karena pada stasiun ini data koherensi belum menunjukkan data yang baik $(75 \%)$ maka dilanjutkan dengan pengolahan timeseries. 


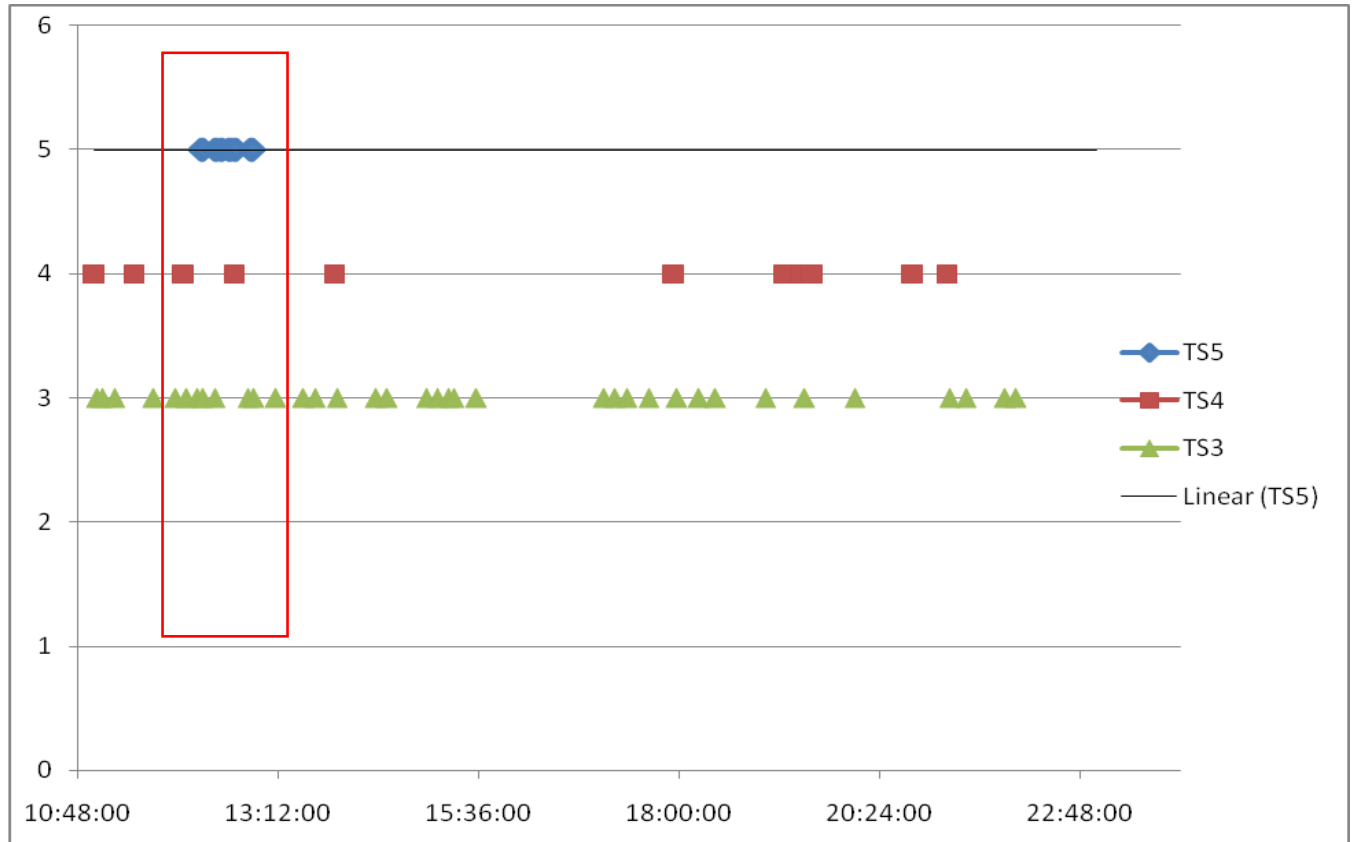

Gambar 5. Proses analisa time series

Pada proses time series dilakukan dengan cara memotong sinyal yang terkena noise koheren. Contohnya yaitu pada rentang waktu pengukuran dari jam 11:00 WIB sampai 23:00 WIB dipotong waktu selama 1 jam 55 menit karena pada rentang waktu tersebut terdapat noise yang ditunjukkan pada kotak merah pada Gambar 5. Acuan perpotongan sinyal ini berdasarkan TS5 yang ditunjukkan pada titik warna biru maka pada rentang waktu tersebut TS4 dan TS3 pun iku terkena noise koheren dan data direduksi.

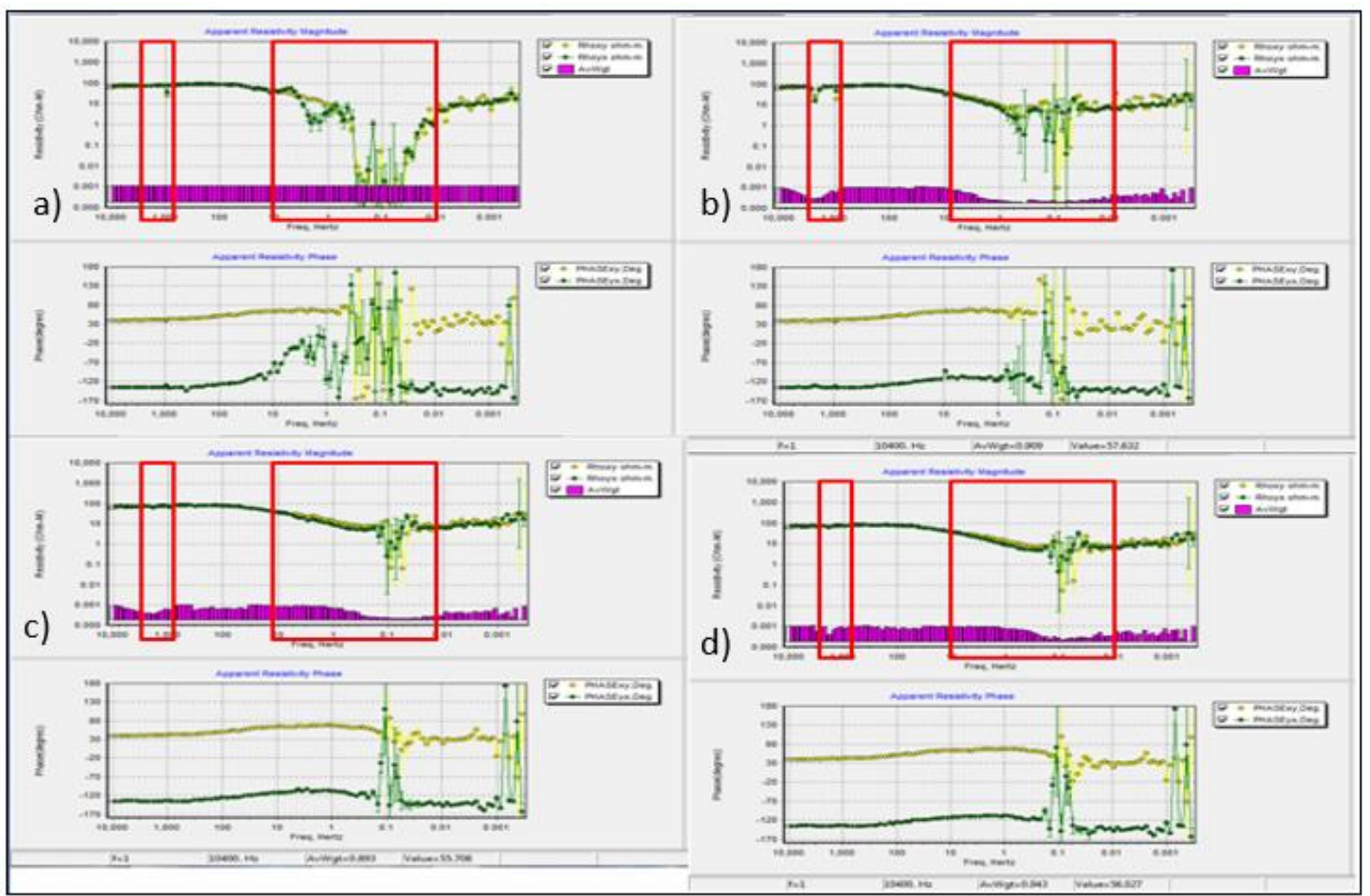

Gambar 6. Grafik appparent resistivity; a) Grafik No Weight(NW); b) Grafik robust ho variance (RV); c) Grafik time tsries; d) Grafik edit XPR 
Berdasarkan pada Gambar 6(c) dilihat dari analisis kualitatif perubahan grafik apparent resistivity terhadap Gambar 6(b) dan 6(a) terjadi perubahan, grafik menjadi lebih smooth jika dibandingkan dengan sebelumnya dan dilihat dari Tabel 1, nilai dari koherensi naik menjadi 78.47\%, naik 4.32\%. Hal ini menunjukkan proses time series berhasil menaikkan nilai koherensi dari yang dibawah $75 \%$ menjadi $>75 \%$. Akhir dari pengolahan ini adalah menggunakan proses edit XPR untuk lebih mendapatkan data yang lebih baik. Dari analisa kualitatif berdasarkan perubahan dari grafik apparen tresistivity pada Gambar 6, ditunjukkan perubahan yang semakin smooth dan bagus pada setiap pengolahan sampai proses edit XPR. Berdasarkan pada Tabel 1, analisisa kuantitatif menunjukkan kenaikan nilai koherensi dari data awal (RAW data) sebesar $67.66 \%$ sampai $81.03 \%$ dan kenaikan koherensi sebesar $13.37 \%$.

Hasil penelitian ini membuktikan bahwa pengukuran metode Magnetotelurik yang dilakukan di tengah kota Bandung yang mempunyai banyak noise. Nilai koherensi yang didapat rata - rata $83.85 \%$ yang menunjukan bahwa data yang dihasilkan dapat diolah lebih lanjut untuk mendapatkan gambaran bawah permukaan. Kenaikan nilai koherensi terbesar terjadi pada stasiun BG13 dimana nilai koherensi dari RAW data (NW) 46.06\% naik menjadi 79.03\% dan kenaikan terkecil pada stasiun BG17 dengan nilai koherensi RAW data (NW) 81.91\% menjadi 89.14\%.

Tabel 1. Hasil Pengolahan Data Magnetotelurik (MT) Berdasarkan Parameter Koherensi

\begin{tabular}{|c|c|c|c|c|c|c|c|c|c|c|c|c|c|c|c|c|}
\hline \multirow{2}{*}{ NoSTAT. } & \multirow{2}{*}{ tgl } & \multirow{2}{*}{$\begin{array}{l}\text { TOTAL } \\
\text { DATA }\end{array}$} & \multirow{2}{*}{ RAW DATA } & \multicolumn{2}{|c|}{ COHERENCY $(\%)$} & \multirow{2}{*}{$\begin{array}{l}\text { AVERAGE } \\
(\% \%)\end{array}$} & \multirow{2}{*}{ ROBUST } & \multicolumn{2}{|c|}{ COHERENCY $(\%)$} & \multirow{2}{*}{$\begin{array}{c}\text { AVERAGE } \\
(\% \%)\end{array}$} & \multicolumn{2}{|c|}{ TIMIE SERIES } & \multirow{2}{*}{$\begin{array}{c}\text { AVERAGE } \\
(\% \%)\end{array}$} & \multicolumn{2}{|c|}{$\mathrm{XPR}$} & \multirow{2}{*}{$\begin{array}{c}\text { AVERAGE } \\
(\% \%)\end{array}$} \\
\hline & & & & RHOXY & RHO YX & & & RHOXY & RHOYX & & RHOXY & RHO YX & & RHOXY & RHO YX & \\
\hline BG_01 & $08 / 03 / 2013$ & 100 & NW & 68.95 & 74.42 & 71.69 & RV & 72.87 & 77.11 & 74.99 & 80.66 & 78.80 & 79.73 & 83.52 & 81.28 & 82.40 \\
\hline BG_02 & $09 / 03 / 2013$ & 100 & NW & 68.58 & 57.77 & 63.18 & OCUPAUTO & 83.98 & 75.14 & 79.56 & 85.19 & 77.11 & 81.15 & 87.80 & 79.94 & 83.87 \\
\hline BG_03 & $05 / 06 / 2013$ & 100 & NW & 66.54 & 74.64 & 70.59 & RVAUTO & 85.33 & 85.60 & 85.46 & 88.45 & 88.89 & 88.67 & 90.68 & 90.44 & 90.56 \\
\hline BG_04 & 09/09/2013 & 100 & NW & 53.64 & 51.81 & 52.72 & RVAUTO & 69.33 & 65.85 & 67.59 & 72.81 & 70.48 & 71.64 & 75.38 & 73.53 & 74.45 \\
\hline BG_05 & $10 / 09 / 2013$ & 100 & NW & 69.78 & 66.29 & 68.03 & OCUPAUTO & 74.65 & 73.96 & 74.31 & 85.53 & 85.67 & 85.60 & 88.01 & 88.33 & 88.17 \\
\hline BG_06 & $11 / 09 / 2013$ & 100 & NW & 63.40 & 74.73 & 69.06 & OCAUTO & 72.51 & 79.97 & 76.24 & 75.14 & 85.07 & 80.10 & 78.58 & 87.01 & 82.79 \\
\hline BG_07 & $12 / 09 / 2013$ & 100 & NW & 60.74 & 57.06 & 58.90 & OCAUTO & 67.15 & 66.51 & 66.83 & 85.98 & 83.08 & 84.53 & 88.11 & 85.58 & 86.84 \\
\hline BG_08 & $02 / 10 / 2013$ & 100 & NW & 52.37 & 69.42 & 60.90 & OCAUTO & 63.28 & 77.77 & 70.53 & 66.86 & 84.04 & 75.45 & 70.93 & 86.82 & 78.87 \\
\hline BG_09 & $03 / 10 / 2013$ & 100 & NW & 73.88 & 80.68 & 77.28 & OCAUTO & 83.21 & 89.42 & 86.31 & 88.12 & 91.52 & 89.82 & 89.24 & 92.46 & 90.85 \\
\hline BG_10 & $04 / 10 / 2013$ & 100 & NW & 61.58 & 76.97 & 69.28 & RVAUTO & 70.52 & 85.26 & 77.89 & 75.48 & 87.56 & 81.52 & 79.39 & 87.99 & 83.69 \\
\hline BG_11 & $31 / 10 / 2013$ & 100 & NW & 65.59 & 69.73 & 67.66 & RVAUTO & 71.84 & 76.41 & 74.12 & 76.12 & 80.82 & 78.47 & 78.97 & 83.09 & 81.03 \\
\hline BG_12 & $01 / 11 / 2013$ & 100 & NW & 70.93 & 57.28 & 64.10 & RVAUTO & 85.88 & 79.35 & 82.62 & 87.20 & 82.01 & 84.60 & 87.84 & 83.43 & 85.63 \\
\hline BG_13 & $02 / 11 / 2013$ & 96 & NW & 42.75 & 49.37 & 46.06 & RVAUTO & 54.18 & 68.39 & 61.28 & 73.73 & 83.18 & 78.46 & 74.45 & 83.60 & 79.03 \\
\hline BG_14 & $04 / 11 / 2013$ & 100 & NW & 77.98 & 67.43 & 72.71 & OCUPAUTO & 85.26 & 77.12 & 81.19 & 88.53 & 87.06 & 87.79 & 90.42 & 89.86 & 90.14 \\
\hline BG_15 & $05 / 11 / 2013$ & 100 & NW & 65.30 & 67.45 & 66.37 & OCAUTO & 74.97 & 75.82 & 75.40 & 78.83 & 80.64 & 79.74 & 82.13 & 83.46 & 82.79 \\
\hline BG_16 & $06 / 11 / 2013$ & 100 & NW & 70.46 & 71.49 & 70.98 & RVUPAUTO & 87.70 & 75.63 & 81.67 & 89.87 & 82.02 & 85.94 & 90.84 & 84.00 & 87.42 \\
\hline BG_17 & $16 / 04 / 2014$ & 100 & NW & 82.01 & 81.82 & 81.91 & OCUP & 83.49 & 84.10 & 83.79 & 85.72 & 87.67 & 86.70 & 87.82 & 90.46 & 89.14 \\
\hline BG_18 & $21 / 08 / 2014$ & 100 & NW & 56.07 & 63.39 & 59.73 & OCAUTO & 65.88 & 72.54 & 69.21 & 75.72 & 78.58 & 77.15 & 80.55 & 81.73 & 81.14 \\
\hline BG_19 & $21 / 04 / 2014$ & 96 & NW & 66.32 & 45.23 & 55.77 & OCAUTO & 75.30 & 57.33 & 66.31 & 79.25 & 80.96 & 80.11 & 82.22 & 83.93 & 83.08 \\
\hline BG_20 & $24 / 03 / 2015$ & 76 & NW & 73.43 & 56.43 & 64.93 & RVAUTOO & 80.88 & 66.81 & 73.84 & 82.84 & 71.51 & 77.18 & 84.61 & 76.04 & 80.32 \\
\hline BG_21 & $25 / 03 / 2015$ & 78 & NW & 58.48 & 51.17 & 54.83 & OCUPAUTO & 76.00 & 65.21 & 70.61 & 75.72 & 66.73 & 71.23 & 79.70 & 72.27 & 75.98 \\
\hline BG_22 & $17 / 02 / 2016$ & 60 & NW & 80.26 & 78.38 & 79.32 & OCUPAUTO & 84.73 & 84.30 & 84.51 & 88.47 & 85.11 & 86.79 & 90.95 & 88.81 & 89.88 \\
\hline BG_23 & $18 / 02 / 2016$ & 100 & NW & 45.03 & 72.51 & 58.77 & OCUPAUTO & 58.70 & 79.56 & 69.13 & 72.25 & 83.62 & 77.94 & 77.91 & 87.04 & 82.47 \\
\hline BG_24 & $11 / 08 / 2016$ & 100 & NW & 70.62 & 73.17 & 71.90 & RVUPAUTO & 77.80 & 83.91 & 80.86 & 82.38 & 87.68 & 85.03 & 84.09 & 88.91 & 86.50 \\
\hline BG_25 & $12 / 08 / 2016$ & 100 & NW & 49.88 & 62.71 & 56.30 & RVUPAUTO & 61.71 & 69.22 & 65.46 & 74.10 & 78.66 & 76.38 & 77.81 & 80.82 & 79.32 \\
\hline
\end{tabular}

\section{KESIMPULAN}

Berdasarkan hasil pengolahan data magnetotelurik menggunakan proses robust, time series, dan edit XPR menghasilkan kenaikan nilai koherensi pada setiap stasiun dengan rata-rata nilai koherensi pada RAW data (NW) sebesar $65.32 \%$ naik menjadi rata-rata nilai koherensi setelah dilakukan pengolahan $83.85 \%$ naik sebesar $18.54 \%$. Pada setiap pengolahan rata-rata nilai koherensi menjadi naik dengan rincian $R A W$ data $65.32 \%$; robust $75.19 \%$; time series $81.27 \%$; dan edit XPR $83.85 \%$. Dari hasil tersebut menunjukkan kualitas data MT menjadi semakin baik karena dilakukannya pengolahan data. Kualitas data MT yang baik dapat lebih merepresentasikan keadaan bawah permukaan kota Bandung hampir sama dengan keadaan sebenarnya.

\section{UCAPAN TERIMAKASIH}

Terimakasih kepada Pusat Survei Geologi yang sudah memberikan izin untuk dilakukannya penelitian ini dan pihak pihak yang terlibat langsung atau pun tidak dalam pembuatan penelitian ini. Terimakasih juga kepada Dewan Direksi Jurnal Mineral Energi dan Lingkungan yang sudah menerbitkan paper/karya tulis ini.

\section{DAFTAR PUSTAKA}

Cagniard, L. (1953). Basic theory of the magneto-telluric method of geophysical prospecting. Geophysics, 18(3), 605635.

Dwiyantoro, R. R., Junursyah, L., \& Yatini, Y. (2018). Rise of Magnetotelluric Data Quality Based on Coherence Prameter in Savu Basin, East Nusa Tenggara. Prosiding ISPG 2018

Egbert, G. D., \& Booker, J. R. (1986). Robust Estimation of Geomagnetic Transfer Functions. Geophysical Journal International, 87(1), 173-194. 
JMEL, Volume 4 Nomor 2, 2020

Hidayat, W., \& Hamdalah, H. (2019). Analisa Geoelectrical Strike Metode AMT untuk Identifikasi Awal Potensi Sistem Panas Bumi di Daerah Gunung Pancar Bogor Jawa Barat. Jurnal Offshore: Oil, Production Facilities and Renewable Energy, 3(1), 23-29.

Hidayat, A. R., Junursyah, G. L., \& Harja, A. S. E. P. (2016). Analisis Deret Waktu Untuk Peningkatan Kualitas Data Magnetotellurik (Studi Kasus Lapangan Geothermal). In Proc. Seminar Nasional Fisika dan Aplikasinya, Universitas Padjadjaran, Jatinangor (pp. 01-10).

Maryani, L., Junursyah, G. M. L., dan Harja, A. (2016). Analisis Deret Waktu (Time Series) Metode Magnetotelurik pada Cekungan Buton, Sulawesi Tenggara. Prosiding SNG 2016.

Mwakirani, R. (2012). Magneto-telluric (MT) Data Processing. Short Course VII on Exploration for Geothermal Resources, Kenya.

Simpson, F., \& Bahr, K. (2005). Practical Magnetotellurics. Cambridge: Cambridge University Press.

Unsworth, M. (2016). Magnetotelluric - Field Techniques. Geophysics424.Canada: University of Alberta.

Vozoff, K. (1990). Magnetotelluric: Principles and Practice. Earth Planet. Phoenix Geophysics, Ltd. 2005. Data Processing Guide. Phoenix Geophysics Ltd. 